\title{
MIRAB: An Image-Guided Multichannel Robot for Prostate Brachytherapy
}

\author{
T. Podder \\ Thomas Jefferson University and Hospitals \\ I. Buzurovic \\ Thomas Jefferson University and Hospitals \\ K. Huang \\ Thomas Jefferson University and Hospitals \\ Y. Yu \\ Thomas Jefferson University and Hospitals
}

Follow this and additional works at: https://jdc.jefferson.edu/bodinejournal

Part of the Oncology Commons

Let us know how access to this document benefits you

\section{Recommended Citation}

Podder, T.; Buzurovic, I.; Huang, K.; and Yu, Y. (2010) "MIRAB: An Image-Guided Multichannel Robot for Prostate Brachytherapy," Bodine Journal: Vol. 3 : Iss. 1 , Article 39.

DOI: https://doi.org/10.29046/TBJ.003.1.038

Available at: https://jdc.jefferson.edu/bodinejournal/vol3/iss1/39

This Article is brought to you for free and open access by the Jefferson Digital Commons. The Jefferson Digital Commons is a service of Thomas Jefferson University's Center for Teaching and Learning (CTL). The Commons is a showcase for Jefferson books and journals, peer-reviewed scholarly publications, unique historical collections from the University archives, and teaching tools. The Jefferson Digital Commons allows researchers and interested readers anywhere in the world to learn about and keep up to date with Jefferson scholarship. This article has been accepted for inclusion in Bodine Journal by an authorized administrator of the Jefferson Digital Commons. For more information, please contact: JeffersonDigitalCommons@jefferson.edu. 


\title{
MIRAB: An Image-Guided Multichannel Robot for Prostate Brachytherapy
}

\author{
Podder, T., Buzurovic, I., Huang, K., Yu, Y.
}

Department of Radiation Oncology, Thomas Jefferson University and Hospitals, Philadelphia, PA

\section{Purpose}

To date, twelve robotic systems have been developed worldwide for brachytherapy, especially for seed implantation. However, the only system that has provision for simultaneous insertion of multiple needles is the MIRAB system. This article reports the feasibility and efficacy of the MIRAB robot as ultrasound image-guided autonomous delivery of radioactive seeds for treating prostate cancers.

\section{Method and Materials}

The Multichannel Image-guided Robotic Assistant for Brachytherapy (MIRAB) has been designed and developed complying Type-B requirements of the IEC-60601guidelines. The MIRAB is a 6-DOF robot capable of inserting and rotating 16 needles concurrently and depositing seeds autonomously according to the dosimetric plan. The MIRAB consists of five modules: Rotary Needle Adapter, Surgical x-y Carrier, Mounting and Driving Mechanism, Seed Applicator, and Transrectal Ultrasound (TRUS) Driver. Numerous techniques perfected by a variety of experiments have been implemented in the system design and development. Therefore, this system possesses several potential advantages such as reduction of target displacement, edema, and operating time as compared to single needle insertion technique. MIRAB's performances (needle placement accuracy, seed delivery accuracy, and reaction force) have been evaluated using soft tissue mimicking material phantom (plastisol gel, i.e. polyvinylchloride) for a wide range of insertion speeds. All 16 needles were inserted simultaneously at $50 \mathrm{~mm} / \mathrm{s}$ speed and then seeds were delivered needle-by-needle using a motorized stylet. Needle and seed positions were evaluated with images taken by high resolution camera, CT, and fluoroscopy.

\section{Results}

From preliminary experimental results, accurate placement of needles was observed (within $0.05 \mathrm{~mm}$ ). The average seed placement error (3D rms error) was about $0.2 \mathrm{~mm}(\mathrm{SD}=0.11 \mathrm{~mm})$. Average relative positional error between seeds was about $0.07 \mathrm{~mm}(\mathrm{SD}=0.05 \mathrm{~mm})$. Needle insertion force was not directly proportional to the number of needles; maximum forces for simultaneous insertion of 2-, 4-, 8-, and 16 -needles were about $19 \mathrm{~N}, 35 \mathrm{~N}, 45 \mathrm{~N}$ and $52 \mathrm{~N}$, respectively $(16 \mathrm{~N}$ for single needle-insertion). These insertion forces also depended on speed of insertion and optimum speed range was about $35-50 \mathrm{~mm} / \mathrm{s}$.

\section{Conclusion}

This study demonstrated the feasibility of implanting seeds for prostate brachytherapy using MIRAB. The preliminary results reveal that the MIRAB is accurate and efficacious in needle placement and seed delivery. Multichannel procedure is faster and potentially can reduce edema and asymmetric displacement of needle and seeds. Effects of simultaneous needle rotation and insertion on target deformation, displacement and reaction forces are being studied.

Acknowledgement: Study funded by DoD (grant W81XWH-06-1-0227). 